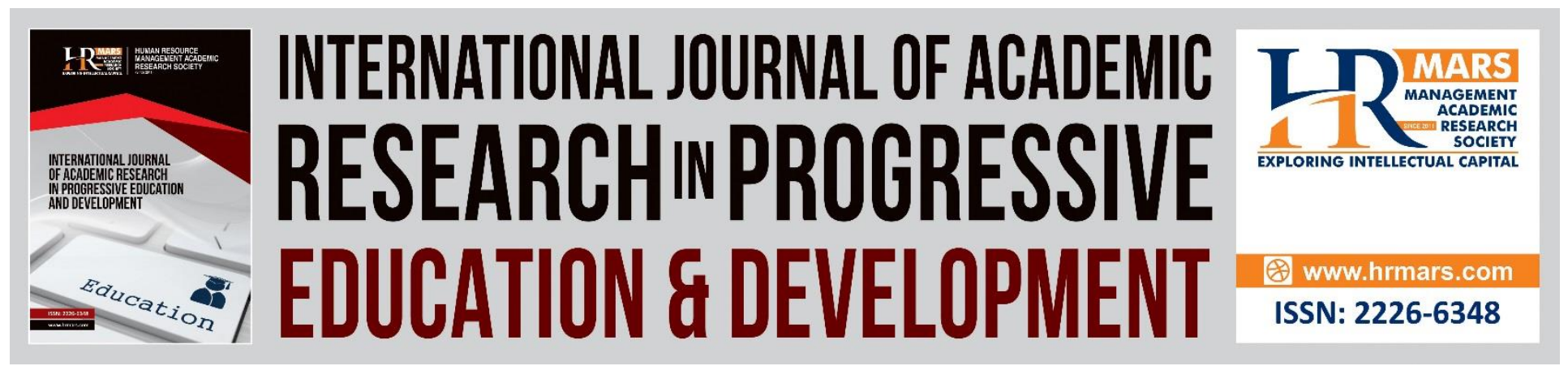

\title{
Application of Computerized Learning Games in Teaching at Karak Schools: Challenges Encountered when Teaching English Language
}

Nesreen Abdullah Khalifeh Khatatneh, Kamarul Shukri Mat Teh

To Link this Article: http://dx.doi.org/10.6007/IJARPED/v7-i3/4430

DOI: $10.6007 /$ IJARPED/v7-i3/4430

Received: 06 August 2018, Revised: 21 August 2018, Accepted: 29 August 2018

Published Online: 04 September 2018

In-Text Citation: (Khatatneh \& Teh, 2018)

To Cite this Article: Khatatneh, N. A. K., \& The, K. S. M. (2018). Application of Computerized Learning Games in Teaching at Karak Schools: Challenges Encountered when Teaching English Language. International Journal of Academic Research in Progressive Education and Development, 7(3), 424-440.

Copyright: (C) 2018 The Author(s)

Published by Human Resource Management Academic Research Society (www.hrmars.com)

This article is published under the Creative Commons Attribution (CC BY 4.0) license. Anyone may reproduce, distribute, translate and create derivative works of this article (for both commercial and non-commercial purposes), subject to full attribution to the original publication and authors. The full terms of this license may be seen at: $\underline{\text { http://creativecommons.org/licences/by/4.0/legalcode }}$

Vol. 7, No. 3, July 2018, Pg. 424 - 440

http://hrmars.com/index.php/pages/detail/IJARPED

JOURNAL HOMEPAGE

Full Terms \& Conditions of access and use can be found at http://hrmars.com/index.php/pages/detail/publication-ethics 


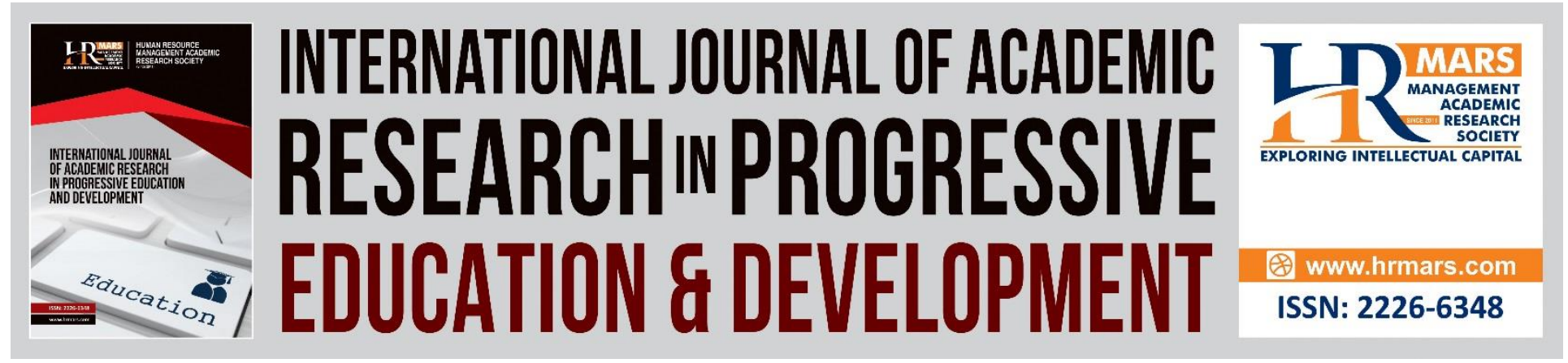

\title{
Application of Computerized Learning Games in Teaching at Karak Schools: Challenges Encountered when Teaching English Language
}

\author{
Nesreen Abdullah Khalifeh Khatatneh \\ Kamarul Shukri Mat The \\ Faculty of Islamic Contemporary Studies, Universiti Sultan Zainal Abidin, Gong Badak Campus, \\ 21300 Kuala Terengganu, Malaysia \\ Email: kamarul@unisza.edu.my, email: nessren201421@gmail.com
}

\begin{abstract}
This study aimed at examining the level of applying computerized learning games in teaching among various schools in Karak metropolis. The study further evaluates the challenges encountered by teachers and the obstacles faced by students in learning English language. To collect the required data for the study, two survey questionnaires were used among the selected teachers. The targeted respondents consist of 82 male and female teachers of English language who teach students at third grade in various schools within the Karak metropolis. Results showed that the level of employing English teachers for computerized learning games in teaching of English for the third grade among various schools of Karak was to a medium degree, while the obstacles faced by students in learning English from the teacher's point of view was at a high degree. Further results showed that, the attitudes of teachers toward the use of computerized learning games in learning English were high. In view of these findings, there is need to recognize the significance and encourage the application of computerized learning games in the teaching of English language to students at the basic stage.
\end{abstract}

Keywords: Computerized Learning Games, Challenges Encountered, Teachers Of English Language.

\section{Introduction}

With the current global arrangement, English is one of the most widely used languages in the world. It is regarded as the world's first language of communication. Millions of people around the world speak and understand the language of science and knowledge. The world is now witnessing an information and knowledge revolution based on foreign languages. As educational institutions were interested in enabling students to learn it alongside mother tongue, English 
INTERNATIONAL JOURNAL OF ACADEMIC RESEARCH IN PROGRESSIVE EDUCATION AND DEVELOPMENT

Vol. 7, No. 3, July 2018, E-ISSN: 2226-6348 @ 2018 HRMARS

language is virtually pronounced in all countries of the world, most especially the third world economies (Al-Ahmadi, 2011).

In a traditional system, the teacher was the sole source of information to the students and the larger community. But in light of the changes that influenced the curriculum, the teacher became a facilitator, an organizer and a guide within the educational process. These changes also affected his role and further limit the teacher's contribution to the targeted audience. Therefore, any changes in the curriculum directly affect all parties in the educational process. Some of these changes include the adoption of computerized learning system in numerous institutions. The modern computerized learning games have become one of the most essential learning system and a significant strategy that is mainly relied in many schools (Al-Khuraisha, 2013).

More so, computer is an educational tool like a blackboard, television or projector. It is also a crucial tool for learning particularly in the contemporary era. The computer literacy increases the thinking capacity and opens up a space for intellectuality that helps learners to read and write (Moneim, 2003). Further evidence as submitted by Al-Khateeb (2002) maintained that using computer as an educational tool helps develop the interaction between the learner and the educational programs that the system provides. This is done by applying computer applications inside the classrooms. These programs are specially designed to teach different subjects and skills.

In addition, Afaneh et al. (2005) indicate that the use of computers enables students to learn at their own speed, and also helps respond to the students as supported by the computer system. It also develops the learner's mental abilities and connects school libraries with the Internet, which encourages access to numerous educational sites and hence considering them as learning games.

According to Abdul-Hadi (2004), computer learning games has the potential to train participants to apply what they have already learned, to clarify the principles derived from the content of the subject, to develop skills in identifying human relations problems, to provide a strong base for research and discussion, to maintain attention, hence the feelings could be observed later from each individual. It also aims to explore participants' feelings, familiarize participants and viewers with scientific material in different- new ways, develop their skills and attitudes toward solving problems, develop empathy towards others and emotional involvement, improves personal problem solving strategies, and help analyze behavioral values and personal behavior.

In Jordan, technology applications are used in education system and is further regarded as a subject for teaching students in automatic and group ways, hence it is the centerpiece of classroom. Among these technological applications include the Eduwave. The Eduwave is an integrated and easy-to-use educational system that works through the Internet. It is used as a portal which allows the educational community to enter the world of technology by integrating itself with knowledge and numerous sources of information as well as developed tools that meet the learners' academic and practical needs. Accordingly, it equally comprises of many developed tools for authoring, spreading curricula and books with the view to improving the skills required and achieving a knowledge-based economy (Majali et al., 2012).

Similarly, the Eduwave is a computerized system approved by the Jordanian Ministry of Education to implement the E-learning system, where different curricula among various classes are computerized and uploaded to the Internet which provides E-learning services to the teachers, students, administrators and parents (Al-Haresh, Mofleh \& Al-Dohoun, 2010). 
Vol. 7, No. 3, July 2018, E-ISSN: 2226-6348 @ 2018 HRMARS

E-learning has several features and advantages, hence it provides learning at anytime and anywhere, and helps students to rely on themselves. This encourages their independence and gives them the freedom and dauntlessness to express themselves in comparison with traditional education. The students receive immediate feedback as long as the self-assessment process and the final evaluation are embedded. The learning resources vary from the links with other educational sites (Abdel Azeez, 2008). Despite the importance of E-learning and the initial results that have proven successfully, this type of education like other education methods, faces some obstacles and challenges that may hinder its use. These challenges include weak infrastructure, poor educational quality, higher development cost, lack of national plan and lack of human interaction which is one of the main obstacles facing the E-learning platform. Other main challenges and obstacles to E-learning system includes lack of effective leadership, inadequate training, and lack of equipment and tools (Earle, 2002).

Furthermore, the biggest obstacle to effective E-learning in various countries include weakness of Internet infrastructure, which limits the speed of data flow and makes the transmission of audio and video troublesome and boring, hence slow transmission. Notwithstanding, the obstacles and challenges facing educational institutions in Jordan and limiting the use of Elearning are: lack of Internet access at various schools, the lack of computer equipment to fit the number of students in the classroom, technical problems that appear in computers and the Internet, lack of equipping the computer lab with the necessary printers, speakers and printing paper, and the lack of possession of a computer at home. Similarly, there are further obstacles facing effective application of information technology in Jordanian schools, thus includes the severe shortage of computers and IT-related equipment, poor effectiveness of teacher training programs in information technology, lack of access to basic Information Technology (IT) skills and competences by school students, and the insufficient time given to the teachers to plan and prepare for applying information technology in teaching processes (Al-Haresh, Mofleh \& AlDohoun, 2010).

\section{Study Problems}

There is a general weakness among students of first basic grades in their achievement and learning of English language. This weakness emanated from several factors and circumstances including teacher-student problems, poor designed curriculum and inefficiency from the students themselves. As indicated by Nofal (2011) who observed that some weakness maybe related to the learners or associated with the traditional methods followed by some poor teaching effectiveness, which is a phenomenon that needs to be taken into account. Certain indoctrination process that are often used by teachers leads to the student being not involved in the educational/learning process and might be distanced from the use models and interactive teaching methods. But, if the learning process incorporates the students perfectly, the students thereafter become more interactive and positive (Tahaineh \& Daana, 2013). For that reason, the modern educational system is eager to avoid traditional methods of teaching and to activate the role of learner towards becoming the base of educational process. Therefore, it is necessary and essential to use modern educational techniques in terms of technological development.

It is highly imperative to note that many teachers lack the mastering computer skills. To a larger extent, this computer skill has now becomes the modern teaching method that many countries relied on. In lieu of that, the Jordanian Ministry of Education has provided a platform that allows 
Vol. 7, No. 3, July 2018, E-ISSN: 2226-6348 @ 2018 HRMARS

the teachers to attend computer courses (ICDL) and other training sessions. In spite of these training programs, the challenges are still noticeable among various institutions. More evidence as supported by Al-Awamleh (2012) reported that there is clear weakness in using computer skills, as such; teachers may avoid teaching through computerized way in order to reduce additional negativity in the system.

According to Alshourafa (2012), the school environment is another added factor that encourages poor performance among students in English language in addition to the school designed curriculum which does not meet students' needs or preference towards learning English. On the other hand, Mumtaz (2001) noted that the most important activities of children in computer games creates favorable atmosphere, makes students feel happy and have fun during learning. It is in view of this issues that this study aimed at identifying the level of English teachers' application of computerized learning games when teaching English language in various classes, teachers attitudes in applying computer skills and the challenges encountered. This is intended to improve the learning system and encourage the application of computer skills in various institutions in Jordan.

\section{Research Questions}

From the foregoing section, various issues and challenges relating to the application of computerized learning games were raised. These issues are summarized and translated into research questions with the view to guiding the study. Among these research questions include the followings:

i. What is the level of applying computerized learning games in teaching of English language for the third-grade students among Karak schools?

ii. What are the challenges and obstacles faced by students in learning English at the third grade from the teacher's point of view?

iii. What are the teachers' attitudes towards applying computerized learning games when learning English?

\section{Study Objectives}

The current study aims to evaluate the level of applying English language on third grade students at Karak schools. This is possible through a designed questionnaire distributed to school teachers with the view to determining the teachers' perceptions and the challenges encountered by third grade students in learning English language. Other specific objective includes the identification of teachers' attitudes toward applying computerized learning games in teaching English language.

\section{Study Importance}

The significance of this study stems from the essential roles played by computerized learning games in teaching process. In order to provide a clear departure from the literature, the study contributed by choosing an effective way to address the weakness of students in learning English language. The study also provides wide horizons for applying computer knowledge among teachers at all schools in Jordan. In addition, the study provides a clear vision and serves as a policy tool for government officials and decision makers at the Ministry of Education with the view to addressing the weakness of learning English language among students. Some of these 
INTERNATIONAL JOURNAL OF ACADEMIC RESEARCH IN PROGRESSIVE EDUCATION AND DEVELOPMENT

Vol. 7, No. 3, July 2018, E-ISSN: 2226-6348 @ 2018 HRMARS

weaknesses as hitherto are due to the application of traditional teaching methods by the English teachers. Hence the growing need by the public authorities and other stakeholders in educational sector to review the teaching process and provides supplementary facilities towards improving the standard in line with the international best practices.

\section{Review of Conceptual and Empirical Literature}

In the literature, there is no consensus among scholars on the precise definition of computerized learning games. Different authors from both developed and developing countries define the concept using certain terminologies. Without knowing the concise meaning of computerized learning games, evaluating its significance will be of no relevance. As define by Al-Helah and Ghnaim (2002), computerized learning games is a purposeful, directed, structured and planned language activity in which students make great efforts to achieve the goals of learning skills in various subjects and fields within specific rules and regulations as described and supervised by the teacher. This computer application also provides the teacher and the learner with an interesting tool when learning the skills. It also provides motives for developing numerous language skills and employ some mental processes (Al-Helah \& Ghnaim, 2002: 598). Another essential concept in this study is the teacher's attitude. As define by Rashid (2009), attitude is a state of readiness among the individual that prompts them to support or not to support a position during a particular circumstance.

However, enormous studies continue to surface the literature on the relevance of computer applications and its significance in educational process and the domain of teaching English language. Among these studies includes Al-Shenaq and Bani Domi (2010) who identifies the attitudes of teachers and students towards applying E-learning skills in the areas of science. The sample consisted of 28 male and female teachers who teach computerized physics for the first grade among scientific secondary students and 118 other students in Karak governorate. Two scales toward E-learning were applied; one for the teachers' attitudes and the other for the students. After performing the necessary estimations, the study found that there were positive attitudes among teachers towards E-learning and also the existence of significant changes in student's attitudes towards E-learning.

In another development, Al-Awamleh (2012) identifies the reality of using computer in teaching at secondary schools in Balqa Governorate and further measure the adequacy of computers peripherals as well as the main obstacles facing teachers in applying computer skills in the teaching process. The study consisted of 400 principals, teachers and students selected randomly as the targeted respondents. To collect the required data, a survey questionnaire was designed and self-administered to the respondents. Based on analytical and descriptive approach, the results indicated to lack of utilizing computers in teaching and the limited use of certain software applications as required by the curriculum. The results further showed a shortage of computers and its accessories even though several computers are old and slow-run; the rest need maintenance. Also, there are no sufficient computers at certain schools that would cover the number of the students. In other word, the ratio of students to computer availability is very marginal and negative.

Similarly, An and Cao (2017) investigated how experience in designing games influences teachers' attitudes and perceptions of use of the digital games in classrooms and the teacher involvement 


\section{INTERNATIONAL JOURNAL OF ACADEMIC RESEARCH IN PROGRESSIVE EDUCATION AND}

DEVELOPMENT

Vol. 7, No. 3, July 2018, E-ISSN: 2226-6348 @ 2018 HRMARS

in educational game design. A total of 50 teachers participated in the study as respondents. Both quantitative and qualitative data were collected from pre- and post-surveys. The results revealed that the game design experience had a positive influence on the participants' attitudes, selfefficacy, and perceptions regarding the use of digital games in the classroom. The result further shows that digital games could help students develop higher-order thinking skills and 21st century skills beyond the making of fun, learning and engaging. After the game design experience, all participants believed that teachers should be involved in the process of educational game design.

Meanwhile, Huizenga, ten Dam, Voogt and Admiraal (2017) examined the practice-based perceptions of teachers who do teach with digital games - either with playing or creating games - in their classroom. Semi-structured interviews were conducted with (43) secondary education teachers. The findings showed that most teachers who actually use games in class perceived student engagement with a game and cognitive learning outcomes as effects of the use of games in formal teaching settings. A few teachers mentioned motivational effects learning by applying digital games.

Likewise, Wohlfarth (2017) analyzed teachers' perceptions of the effects on students' character and academic performance that teachers attribute to the games. The sample consisted of (54) secondary-school teachers who experienced EnTeam games. The study uses qualitative research with semi-structured interviews and thematic analysis. The results show that teachers discern gains in academic achievement and character development when students learn together applying games that keep score of cooperative performances. Teachers also identified challenges in applying these games that teachers do not see the full benefit from the games unless they empower students to engage in the games, give students license to make real choices about how to improve their goal attainment, and allocate time for students to learn from experience.

Nevertheless, Stieler-Hunt and Jones (2017) investigated the experiences of (13) Australian teachers who have used immersive digital games in the classroom. Those teachers participated in in-depth, semi-structured interviews that were one to two hours long. They main finding that the study concluded to is that teachers who use immersive digital games in the classroom can experience varying degrees of alienation from their teaching colleagues. The study concludes to, while a teacher has negative attitudes towards the use of immersive digital games in the classroom, the potential impact of immersive digital games in the classroom would not be fully realized.

\section{Methodology and Estimation Procedures}

This study applied the survey methodology which describes the reality given by the study population who study it as it is, describe it precisely, express it by quantity and quality, within administrative survey based on references and previous studies in line with published research to construct the theoretical framework and field search to collect information by applying study instrument and gets it analyzed statistically enough to answer the study questions.

To estimate the results and for the purpose of answering the study questions, a Statistical Package for Social Sciences (SPSS) was applied in the estimation process, applying descriptive statistical measures to determine the level of applying of computerized learning games by teachers of English in teaching English based on frequencies, percentages, means and standard deviations, to analyze teachers' perceptions of the obstacles that students face in learning English 
Vol. 7, No. 3, July 2018, E-ISSN: 2226-6348 @ 2018 HRMARS

based on frequencies, percentages, means and standard deviations, and finally to identify attitudes in applying computerized learning games in learning English based on frequencies, percentages, means and standard deviations.

\section{Study Population and Sample Size}

The population of this study consists of all male and female English teachers who teach the third grade at the fourth Karak government schools (Directorate of Qasbah, Directorate of the Qasr, Directorate of Southern Mazar, Directorate of the Southern Ghours). A total of 82 male and female teachers were selected from various schools where the third grades are being taught. The study adopts a simple random sampling technique in selecting the targeted respondents. Evidence from Table 1.1 shows the demographic information and descriptive statistics of the targeted respondents.

Table 1.1: Descriptive statistics of the targeted respondents

\begin{tabular}{llcc}
\hline \multicolumn{1}{c}{ Variables } & \multicolumn{1}{c}{ Category } & Frequency & Percentage \\
\hline Gender & Male & 34 & 41.5 \\
& Female & 48 & 58.5 \\
\multirow{3}{*}{ Education } & Total & 82 & 100.0 \\
& Bachelor & 47 & 57.3 \\
& Bachelor + higher & 22 & 26.8 \\
& Diploma & 13 & 15.9 \\
\multirow{3}{*}{ Experience by } & Postgraduates & 82 & 100.0 \\
years & Total & 26 & 31.7 \\
& Less than 5 & 42 & 51.2 \\
& 5-10 & 14 & 17.1 \\
& More than 10 & 82 & 100.0 \\
\hline
\end{tabular}

\section{Data Coding and Transformation}

After the questionnaire had been distributed to the teachers, who constituted the sample of the study, and to ensure the handover of the questionnaire to each teacher by hand, and to clarify the objectives of the questionnaire about how answering the items, it was collected after two days. Also, after getting the validity of the instrument of the tool for statistical analysis attained, and the data entered electronically, and for the purpose of classifying the use of learning games by teachers of English of the third grade students, the values of the means of the sample responses of the study were determined by teachers as follows:

i. When the value of the mean is 3.68 to 5 , the level of applying of learning games by teachers of English language in their view is high-that is, almost teachers of English language apply computerized learning games, and they have clear preparations to improve their skills.

ii. When the value of the mean is 2.34 to 3.67, the level of applying of computerized learning games by teachers of English language is medium. That is to say, many English teachers apply computerized learning games, but they have clear preparations for developing their skills to apply those games. 
Vol. 7, No. 3, July 2018, E-ISSN: 2226-6348 @ 2018 HRMARS

iii. When the value of the mean is 1 to 2.33 , the level of applying computerized learning games by teachers of English language in their view is low, it does mean that a few English teachers apply those games, and they therefore need to improve their skills to apply computerized learning games.

\section{Research Instrument}

The research is based on the questionnaire as an instrument for collecting data from teachers, after theoretical literature and previous studies of (Al-Khaldi, 2012; Al-Emteri, 2008; Al Hassan, 2012) had been studied. The first questionnaire is designed to evaluate the level of applying computerized learning games by the teachers and the challenges encountered by students when learning English. The questionnaire consisted of personal information of teachers. While the second section consists of 24 items, it measures the level of applying computerized learning games by English teachers. This section is divided into four domains: the achieving educational goals, the availability of educational curriculum, learning games as a source of knowledge, and proficiency in language skills. The third section consists of 25 items to detect the obstacles facing students in learning English at the third grade. This section is divided into four domains: problems related to the curriculum, problems related to the teacher, problems related to the student, and problems related to the school.

The second category of the questionnaire is on the attitudes of teachers towards applying computerized learning games in teaching English language. The research was based on the questionnaire as an instrument for collecting data from teachers, after reviewing the theoretical literature and previous studies of (Al-Shenaq \& Bani Domi, 2010; Jabr \& Wajih, 2007). This questionnaire consisted of personal information of teachers. While the second section consists of (21) items, measuring the attitudes of teachers towards applying computerized learning games in teaching English.

\section{Instrument Validity}

The first questionnaire was examined using the content validity (validity of the experts) in order to ensure the validity of the questionnaire by presenting it in its preliminary form to a committee consisted of five (5) exports from the faculty of Jordanian universities and who are specialized in the field of teaching methods, measurement and evaluation, and in educational management in order to ascertain the validity of questionnaire items, the accuracy of resolution wording items, the accuracy and clarity of the item, the relevance of each item to its domain, its suitability to achieve the objective for which it was prepared, and to delete, add or modify any suggestions sound appropriate. So, upon being the experts' views and suggestions had taken into consideration, few items were amended, deleted and removed by the arbitrators based on the consensus of the majority of the experts on the amendment procedure and the finalization of the questionnaire.

To derive the valid indicators for all items of the questionnaire, they were applied to a survey sample of 30 teachers from the same study population and the Pearson Correlation Coefficient between each item and its domain and the questionnaire as a whole is presented as follows: 
INTERNATIONAL JOURNAL OF ACADEMIC RESEARCH IN PROGRESSIVE EDUCATION AND DEVELOPMENT

Vol. 7, No. 3, July 2018, E-ISSN: 2226-6348 @ 2018 HRMARS

Table 1.2: Reliability by Cronbach's Alpha and Test-Retest values

\begin{tabular}{llccc}
\hline No. & Domain & N. & Cronbach's Alpha & Test-Retest \\
\hline 1 & $\begin{array}{l}\text { Achieving educational goals. } \\
\text { Availability of educational }\end{array}$ & 6 & 0.79 & 0.81 \\
$\begin{array}{l}\text { curriculum. } \\
\text { Learning games as a source of } \\
\text { knowledge. }\end{array}$ & 6 & 0.84 & 0.82 \\
$4 \quad$ Proficiency in language skills & 6 & 0.85 & 0.84 \\
\hline $\begin{array}{l}\text { Computerized learning games applied } \\
\text { by the teachers. }\end{array}$ & 24 & 0.82 & 0.83 \\
\hline $1 \quad \begin{array}{l}\text { Problems related to curriculum. } \\
2\end{array}$ & 7 & 0.80 & 0.90 \\
\hline $\begin{array}{l}\text { Problems related to the } \\
\text { teacher. }\end{array}$ & 6 & 0.78 & 0.81 \\
$\begin{array}{l}\text { Problems related to the } \\
\text { student. }\end{array}$ & 6 & 0.81 & 0.79 \\
$\begin{array}{l}\text { Problems related to the school. } \\
\text { The obstacles that students face when }\end{array}$ & 6 & 0.77 & 0.83 \\
learning English language & 25 & 0.83 & 0.82 \\
\hline
\end{tabular}

Information from Table 1.2 shows that the Cronbach's Alpha coefficients for the study domains were between 0.77 and 0.89 , and all reliability coefficients are high and satisfied for the study. Also, the reliability factor (Cronbach's Alpha) is satisfied once exceeds 0.70 . While Test-Retest coefficients for the domains were between 0.79 - 0.90, and all t-retest reliability coefficients were high and satisfied for study purposes, where the coefficient of t-retest reliability is satisfied once exceeds 0.70 .

For the second questionnaire, the reliability test was also conducted and confirmed by applying it to a survey sample from the research population and from outside the sample itself. The sample consisted of 30 male and female teachers and it was applied two times within two weeks on the same survey sample. Then, Pearson correlation coefficient was computed between the two applications to extract the reliability of Test-Retest on one hand, and to confirm the reliability of the instrument by extracting the reliability coefficient applying the Cronbach's Alpha equation on the other. Cronbach's Alpha coefficients were applied to identify the questionnaire "teachers' attitudes towards applying computerized learning game in teaching" at 0.88 . Whereas the reliability coefficients of the questionnaire "teachers' attitudes toward computerized learning games" at 0.89 . So, all t-retest coefficients are high and satisfied, where the coefficient of t-Retest is satisfied once exceeds 0.70 .

\section{Results and Implications}

To answer the first questionnaire, the means and standard deviations for were computed for each of the domains and the scale "applying computerized learning games by teachers of English" as a whole, as illustrated in Table 1.3. 
INTERNATIONAL JOURNAL OF ACADEMIC RESEARCH IN PROGRESSIVE EDUCATION AND DEVELOPMENT

Vol. 7, No. 3, July 2018, E-ISSN: 2226-6348 @ 2018 HRMARS

Table 1.3: Means and standard deviations of the" applying computerized learning games by teachers of English" and the scale as a whole ( $N=82)$

\begin{tabular}{llcccc}
\hline No. & \multicolumn{1}{c}{ Domain } & Mean & Std Dev. & Rank & Degree \\
\hline 1 & $\begin{array}{l}\text { Achieving educational } \\
\text { goals. } \\
2\end{array}$ & 2.77 & 0.22 & 4 & Medium \\
$\begin{array}{l}\text { Availability of educational } \\
\text { curriculum. }\end{array}$ & 2.81 & 0.25 & 3 & Medium \\
$3 \quad \begin{array}{l}\text { Learning games as a source } \\
\text { of knowledge. }\end{array}$ & 2.88 & 0.20 & 2 & Medium \\
$\begin{array}{l}\text { Proficiency in language } \\
\text { skills. }\end{array}$ & 2.89 & 0.19 & 1 & Medium \\
\hline The scale as a whole & 2.84 & 0.16 & - & Medium \\
\hline
\end{tabular}

Estimated findings from Table 1.3 shows that the means for the domains of the scale were 2.77 to 2.89 , where the highest mean was for the fourth domain, "proficiency in language skills" with mean of 2.89 and to medium degree. Followed by the third domain "learning games as a knowledge source" with mean of 2.88 and to medium degree. Then, the second domain, availability of educational curriculum, has a mean of 2.81 to medium degree. Lastly, the first domain, achieving educational goals, has a mean of 2.77 and to medium degree. While the mean for the scale" applying computerized learning games by teachers of English" as a whole is 2.84 and to medium degree.

As aforementioned, the results showed that the most prominent indexes of applying computerized learning games by the teachers: is that to apply learning games that attract students to learn, enjoy and entertain, make pre-planning when applying learning games in teaching, apply learning games to do competitions in English for the student, and to enhance students' reading comprehension skills as well.

Therefore, the results showed that the level of applying computerized learning games by teachers of English in teaching English language for the third grade at Karak schools was medium. The highest axis concentrates on proficiency of language skills and the lowest concentrates on achievement of educational goals. The researcher justifies that the teachers of English recognize the importance of applying learning games in providing students with proficiency in English language skills, and making the curriculum easier and simpler for students, especially as it is a difficult subject they study.

Unfortunately, there are obstacles that prevent teachers from applying computerized learning games to achieve educational goals such as limited tools, equipment and devices available, and overcrowded classrooms. English teachers who teach at the third-grade students at Karak schools apply learning games that attract students to learn and achieve with fun and entertainment. They also focus on selecting learning games that suit students' abilities and educational levels to enable them acquire the necessary language competencies commensurate with the educational objectives to be achieved accurately. Moreover, teachers seek to choose learning games that will attract students to learn and bring them enjoyment and get them interested at the same time. Learning games, therefore, are a means of achieving cognitive and mental growth, as well as a means of recreation and spend free times. 
Vol. 7, No. 3, July 2018, E-ISSN: 2226-6348 @ 2018 HRMARS

As supported by Huizenga, Ten Dam, Voogt and Admiraal (2017) that most teachers who apply games in teaching believe that they contribute to the development of student participation and learning outcomes. Besides, An and Cao (2017) note that apply digital games can help students develop upper thinking skills, increase their fun and participate in learning.

For answering the second question, the means and standard deviations for each of the domains and the measure "the obstacles that students face in learning English" were computed as a whole, as shown in Table 1.4.

Table 1.4: Means and standard deviations of "the obstacles that students face in learning English" and the scale as a whole ( $N=82)$

\begin{tabular}{clcccc}
\hline No. & \multicolumn{1}{c}{ Domain } & Mean & Std Dev. & Rank & Degree \\
\hline 1. & $\begin{array}{l}\text { Problems related to } \\
\text { curriculum. }\end{array}$ & 3.87 & 0.43 & 3 & High \\
2. $\begin{array}{l}\text { Problems related to the } \\
\text { teacher. }\end{array}$ & 3.84 & 0.42 & 4 & High \\
3. $\begin{array}{l}\text { Problems related to the } \\
\text { student. }\end{array}$ & 3.98 & 0.48 & 1 & High \\
4. Problems related to the & 3.97 & 0.38 & 2 & High \\
$\quad$ school. & 3.91 & 0.27 & - & High \\
\hline The scale as a whole & & & & &
\end{tabular}

Table 1.4 shows that the means of the scale domains were at 3.84 to 3.98 , and the highest for the third domain "problems related to the student" with a mean of 3.98 and to high degree, followed by the fourth domain "problems related to the school" with a mean of 3.97 to a high degree, and then the first domain, "problems related to the curriculum" with mean of 3.87 and to a high degree. Then, the second domain "problems related to the teacher" with mean of 3.84 and to a high degree. While the mean of the "obstacles that students face in learning English" as a whole is at 3.91. The results further showed that the main obstacles faced by students in learning English from the point of view of teachers are: The content of the curriculum does not range from easy to difficult, teacher have less command of English language skills, the interest of students to learn a certain skill at the expense of another like interest in learning grammar, and inappropriate classroom used to apply teaching methods alongside modern teaching techniques. Moreover, the findings also indicated that the level of obstacles faced by students in learning English at the third grade from the point of view of teachers were high in terms of curriculum, student and teacher, and the school. Problems related to students were at high degree, the researcher explained that there is a weakness in the level of students' knowledge of English language skills and the difficulty of understanding English from the students' point of view. Also, students are interested in learning one skill at the expense of the other, such as interested in learning grammar. While problems related to the teacher were at low degree.

The researcher justifies that guidance and instructions are poorly given to teacher's knowledge of English language skills. The curriculum does not include sufficient motivational and effective activities that help to master English language skills. Curriculum content does not range from easy to difficult. There are certain kinds of deficiencies in the observance of the interdependence 
INTERNATIONAL JOURNAL OF ACADEMIC RESEARCH IN PROGRESSIVE EDUCATION AND DEVELOPMENT

Vol. 7, No. 3, July 2018, E-ISSN: 2226-6348 @ 2018 HRMARS

of the units and subjects of the book, in addition to the lack of clarity in the way the subject in the English language book presents.

Regarding schools, there are many classrooms are not appropriate to apply the means of teaching modern technology yet, and they are not technologically-equipped with modern devices that may apply computerized learning games in line with overcrowded classrooms, which is a barrier to the process of education well and smoothly. This result is consistent with the study of AlAwamleh (2012) which showed a shortage of computers and accessories, in addition some of them were slow-run, unsuitable to be used and they need maintenance, and there are not enough computers compared to the number of students as well. It is also consistent with StielerHunt and Jones (2017) who suggest that teachers who use immersive digital games in the classroom can face different degrees of isolation from their classmates, reflecting negatively on the potential positive impact of immersive digital games in the classroom. In similar context, the study of (Wohlfarth, 2017) indicates that teachers do not see full use of the applying games in teaching unless they encourage students to participate in them, and this gives students more time to learn from experiencing games.

For the third question, similar estimation procedures were applied. The means and standard deviations were computed for each of the "teacher's attitudes towards computerized learning games in learning English" as a whole. The results showed that the means of the scale were 3.45 to 4.27 , and high to the item 14, which states that "applying learning games in teaching contributes to improving the quality of teaching" with mean of 4.27 and to high degree. Followed by item 17, which states that "applying computerized learning games in teaching students to selflearning" with mean of 4.22 and to a high degree. Then, item 16, which states that "applying computerized learning games in teaching helps to simplify the subject and make it more clear" with mean 4.12 and to a high degree. At the last rank was item six (6), which states that "applying computerized learning games in teaching helps to make education enjoyable and exciting for students" with mean of 3.45 and to a medium degree.

Thus, the mean of "teachers' attitudes toward computerized learning games in English" as a whole was at 3.91 and to a high degree. Generally speaking, the results showed that teachers' attitudes towards applying computerized learning games in learning English were high. The researcher sees that learning games contribute to the learner's understanding of concepts, information and knowledge about the surrounding science. Through play, as the researcher sees, students can recognize the characteristics of tangible objects; their similarities and differences. Additionally, learning games help self-knowledge, through experience and exploration, the learner can recognize what he likes and tends to certain object, recognizes what corresponds to the potential, and it helps him to identify the national problem and how to overcome them as well.

Regarding teachers, they see when applying computerized learning games to teach English, games save time, increase the effectiveness of students in the classroom, increase the ability of students to retain information, increase the motivation of students to learn, students participate and work together, encourage them to think critically and to deduct, develop students' creative skills, as well as help take into account the individual differences between students through the possibility of choosing the game which suits their levels mentally and academically. This method helps the teacher to adopt self-leaning strategy, helps him/her become a mentor and a guide rather being only speaker, and helps reduce her/his teaching time-table. 


\section{INTERNATIONAL JOURNAL OF ACADEMIC RESEARCH IN PROGRESSIVE EDUCATION AND}

DEVELOPMENT

Vol. 7, No. 3, July 2018, E-ISSN: 2226-6348 @ 2018 HRMARS

Additionally, computerized learning games contribute to improving the quality of teaching and learning outcomes, making the material more visible, providing effective assessment and feedback to students, and the ability to remember information quicker at the time of the exam. The highest items of the teachers' attitudes towards applying computerized learning games in learning English were " "applying computerized learning games in teaching contributes to improving the quality of teaching" and "applying computerized learning games helps students to learn by self-learning." The researcher justifies that teaching by applying electronic learning games contributes to encouraging students to learn, think and make conclusions, develop the creative skills, to adopt self-learning, and encourage teamwork among students.

On the other hand, applying computerized learning games help teachers to do what it must be done throughout delivering information and encouraging students to learn and retain information. If doing so, students are able to recall the information and do well in exams, and mirror high marks later. Basically, this is the main goal that teachers seek to attain, when it comes to applying computerized learning games. The lowest item indicates that was that "applying computerized learning games in teaching to make education enjoyable and exciting for students."

The researcher puts it well that computerized learning games are means to communicate the information written in the book in a new and easy way. Since the more interesting and powerful the place is, the greater the student's understanding of information and ideas and the more the student attaches to the subject matter, as indicated by Wohlfarth (2017) that the use of games in teaching contributes to improving the academic achievement of students and develop their personality from the point of view of teachers. Also, it was pointed out by An and Cao (2017) that digital games had a positive impact on teachers' attitudes, self-efficacy, and their perceptions regarding the use of digital games in the classroom.

\section{Conclusions}

When teaching English language for the third grade at schools of Karak, the teachers apply computerized learning games to a medium degree; but it was not enough as planned as it must be. The domain of applying computerized learning games which focuses on proficiency in language skills is higher than the other domains (the domain of achievement of educational goals, the domain of applying learning games as a source of knowledge and the domain of availability of school subject). In addition, it is noted that there were obstacles face students in learning English at the third grade from the point of view of teachers to high degrees, whereas the most prominent problems refer to the students themselves. More so, the study revealed that there are positive and high tendencies among teachers to greatly apply computerized learning games in learning English, because applying such games especially in teaching contributes in improving the quality of teaching self-learning among students, simplifying the subject matters, making it more clear, providing feedback to students, as well as adding a lot of positive attitudes needed.

\section{Recommendations}

Base on the estimated findings, the study recommends the following policy issues both to the government and analyst. There is a growing need to pay attention to apply computerized learning games in teaching English language skills for students at the basic grade. Likewise, the Ministry of Education should provide the facilities and electronic and technological devices necessary for 
Vol. 7, No. 3, July 2018, E-ISSN: 2226-6348 @ 2018 HRMARS

applying computerized learning games to teach English and developing its skills (reading, writing, listening, and speaking) among students alongside providing special English language laboratory equipped with required necessities to teach English by up-to-date and developed manner at each school. In addition, the Ministry of Education should hold training courses for teachers to apply computerized learning games when teaching English on one side, and help teachers learn new teaching methods and apply modern methods to improving the learning process on the other side. Also, further studies should be conducted on E-learning in all its forms, types and methods and see how much benefit we may get from teaching English by a modern and developed manner which keeps pace with the nature of the enormous technological changes.

\section{Acknowledgement}

This article is part of a research fund sponsored by Center for Research and Innovation (RMIC), Universiti Sultan Zainal Abidin (UniSZA), Gong Badak Campus 21300 Kuala Nerus, Terengganu.

\section{References}

Al-Ahmadi, A. A. (2011). The impact of applying learning games in the acquisition of students of the sixth grade primary alphabets and vocabulary of the English language in Jeddah (unpublished master's thesis). University of Umm al-Qura, Saudi Arabia.

Al Hassan, M. H. M. (2012). Problems facing the performance of English Language Teachers at Secondary Schools in Mahayel Asir Governorate (unpublished Master's Thesis). Umm Al Qura University, Saudi Arabia.

Jabr, W., \& Wajih J. (2007). The impact of computer use on the achievement of seventh grade students in mathematics and their teachers' attitudes towards its use as an educational tool (unpublished master's thesis). Al-Najah National University, Palestine.

Al-Helah, M. M. \& Ghnaim, A. A (2002). The effect of computerized and traditional language learning games in addressing reading difficulties among grade students. Al-Najah University Journal of Research, Humanities, 16 (2). 589-626.

Al-Khaldi, F. (2012). The level of employment of Arabic language teachers in the secondary stage of technological innovations in light of the overall quality standards (unpublished master's thesis). Islamic University, Gaza Palestine.

Al-Khuraisha, A. A. (2013). Foundations of curriculum and language. Amman: Dar Al-Hamed Publishing and Distribution.

Al-Khateeb, L. (2002). Basics in computer tutorial (11 ${ }^{\text {th }}$ ed). Irbid, Jordan: Dar Al Kotob for Distribution.

Rashid, M. (2009). Mathematics curriculum and teaching methods for the basic classes. Amman: Janadriyah Dar for Publishing and Distribution.

Al-Shunaq, Q., \& Bani, D.H. (2010). Attitudes of teachers and students towards the use of Elearning in Jordanian secondary schools. University of Damascus Journal, 26 (1), 235-271.

Abdel Azeez, H. (2008). E-learning philosophy - principles - tools - applications. Amman: Dar AlFikr.

Abdel Moneim, R. (2003). The difficulties faced by the students of the tenth grade in Gaza Governorate in the use of computers and their relation to some variables (Master's thesis). Islamic University, Gaza, Palestine. 
Vol. 7, No. 3, July 2018, E-ISSN: 2226-6348 @ 2018 HRMARS

Abdul Hadi, N. (2004). The psychology of play and its impact on children's learning. Amman: Dar Wael Publishing and Distribution.

Afaneh, E., Khazandar, N, Mehdi, H. \& Kahlout, N. (2005). Computer teaching methods ( $1^{\text {st }}$ ed). Gaza: Horizons for Printing and Publishing.

Al-Awamleh, K. A. (2012). The reality of computer use in teaching from the point of view of principals, teachers and students in the secondary schools of Balqa Governorate. Dirasat Journal, Educational Sciences, 39 (2), 428-450.

Al-Emteri, M. E. (2008). Teaching problems of the English language teachers at the primary level (unpublished Master's thesis). Umm Al-Qura University, Saudi Arabia.

Majali, M.D., Al-Nisour, Z.A., Hamad, M.A, Hattab, K.Z., Zboun, H.S., \& Matari, R.O. (2013). A comparative study of the extent to which mathematics, Arabic and English teachers use computerized curricula on the EduWave E-learning system in exploratory schools. Studies, Educational Sciences, 39 (1), 171-194.

Nofal, K. (2001). Reasons for the weakness of the students of the Department of English at Philadelphia University. Journal of University of Damascus, 27 (1 + 2), 751-772.

Al-Haresh, A., Mofleh, M., \& Al-Dohoun, M. (2010). Obstacles to the use of E-learning system from the point of view of secondary school teachers in the district of Koura. Jordanian Journal of Educational Sciences, $6 \quad$ (40), 27 - 40.

Alshourafa, A. (2012). The effect of motivation on Jordanian 10th grade students' writing skills in English. European Scientific Journal, 8 (22), 235-247.

Earle, R. S. (2002). The integration of instructional technology into public education: Promises and challenges. Educational Technology-Saddle Brook Then Englewood CLIFFS NJ-, 42(1), 5-13.

Huizenga, J. C., ten Dam, G. T. M., Voogt, J. M., \& Admiraal, W. F. (2017). Teacher perceptions of the value of game-based learning in secondary education. Computers and Education, 110, 105-115.

Mumtaz, S. (2001). Children's enjoyment and perception of computer use in the home and the school. Computers and Education, 36 (4), 347-362.

Stieler-Hunt, C. J., \& Jones, C. M. (2017). Feeling alienated-teachers applying immersive digital games in classrooms. Technology, Pedagogy and Education, 26 (4), 457-470.

Tahaineh, Y., \& Daana, H. (2013). Jordanian undergraduates' motivations and attitudes towards learning English in EFL context. International review of social sciences and humanities, 4(2), 159-180.

Wohlfarth, T. A. (2017). Teachers' Perceptions of Learning games that Keep Score of Cooperative Performances (Doctoral dissertation). University of Missouri-Saint Louis.

An, Y. J., \& Cao, L. (2017). The Effects of Game Design Experience on Teachers' Attitudes and Perceptions regarding the Use of Digital Games in the Classroom. TechTrends, 61 (2), 162170. 